\title{
Print-Based Media in Methodology Course of Classroom Action Research
}

\author{
Jalaludin \\ Universitas Islam Negeri Sulthan Thaha Saifuddin Jambi \\ jalaludinuinjambi@gmail.com \\ Mona Novita \\ Institut Agama Islam Yasni Bungo \\ monanovita@iaiyasnibungo.ac.id \\ Nova Asvio \\ Universitas Islam Negeri Fatmawati Sukarno Bengkulu \\ novaasvio@iainbengkulu.ac.id \\ Article History: Received on 2 November 2021, Revised on 27 December 2021 \\ Published on 14 January 2022
}

\begin{abstract}
Research with the Research and Development (R\&D) Method was carried out to produce products in the form of printed learning textbooks as a complement to printed materials in the methodology course of Class Action Research (CAR) at the State Islamic University (UIN) Sulthan Thaha Saifuddin Jambi. This study was divided into three stages: 1) defining; 2) planning and development; and 3) dissemination. The research data were analyzed using domain analysis techniques with critical and reflective principles. Findings printed media for learning textbooks for the CAR methodology course have been developed based on a process approach. The book consists of eleven chapters, covering: 1) recall of CAR concepts; 2) research techniques and CAR data collection instruments; 3) observation sheet; 4) interview sheet; 5) test sheet; 6) questionnaire sheet; 7) documentation in CAR; 8) analysis techniques in CAR; 9) dissemination of CAR reports; 10) write articles from the results of the CAR; and 11) writing a book based on the results of the CAR. The purpose of learning with print media is to help students learn the CAR methodology easily and make learning interesting and fun and enable them to study independently. The developed learning print media is claimed to be suitable for use through a feasibility test carried out by material and media experts to practice making CAR proposals or reports to publishing articles and books with ISBN from the CAR results.
\end{abstract}

Keywords: Media Development, Print, Classroom Action Research

\section{A. Introduction}

Teaching materials are one of the important factors in the effectiveness of learning, especially at the Higher Education level (Arsanti, 2018). Teaching materials are a set of learning tools or tools that contain learning materials, methods, limitations, and evaluation methods that are designed systematically and attractively in order to achieve the expected goals, namely achieving competence or sub-competence with all its complexity (Widodo \& Jasmadi, 2008). So, teaching materials are a means to achieve the objectives of learning a course.

Textbooks are one of the printed media of teaching materials. Books as teaching materials are learning resources that contain knowledge from the analysis of the curriculum in written form. 
Books are arranged using simple, attractive language, equipped with pictures, descriptions, book contents, and bibliography. Books will greatly assist educators and students in exploring science according to their respective subjects. Textbooks have an important position and function in learning activities (Astuti et al., 2020; Depdiknas, 2006; Eriyadi, 2008; Muslich, 2010).

One of the courses that require textbooks that suit the needs of students is the CAR methodology course. This information was obtained from the results of interviews with researchers from the Tarbiyah and Teacher Training Faculty (FTK) of UIN Sulthan Thaha Saifuddin Jambi. Students revealed that there were obstacles in finding a source book that specifically discussed the CAR methodology to writing articles and books from the CAR results. Meanwhile, based on the early observations, it was discovered that the average student had difficulty selecting the CAR data gathering instrument. This observation was carried out by distributing a data collection instrument package (IPD) consisting of 2 questionnaires and 3 observation sheets to 50 PGMI students, 30 PIAUD students and 30 Tadris Physics students and 30 Biology students at UIN Sulthan Thaha Saifuddin Jambi.

The CAR methodology course is a compulsory subject at a university. The learning outcomes possessed by students after taking the CAR methodology course are assessments of soft skills: 1) fear of God Almighty and are able to demonstrate religious attitudes in individual, community and national life; 2) demonstrate a responsible attitude towards work in the field of expertise independently; 3) present oneself as an honest person, with noble character, and an example for students and the community; and 4) demonstrate work ethic, responsibility, pride, self-confidence and love to be an educator in the field of classroom teachers covering Indonesian language, Pancasila and citizenship education, mathematics, natural sciences and social sciences in school/madrasah education units (SD/MI).

Assessment on hard skills includes: 1) mastering knowledge and steps in developing critical, logical, creative, innovative and systematic thinking and having an intellectual curiosity to solve problems at individual and group levels in academic and non-academic communities; 2) mastering scientific research theory for MI/SD Class teachers in the framework of taking reflective action to improve quality and innovative steps in teaching MI/SD class teachers; 3) mastering learning theory and teaching learning principles in the implementation of learning in the MI/SD Class Teacher field (fields of study in Civics, Indonesian Language, Mathematics, Natural Sciences, Social Sciences); and 4) Mastering the substance of the material, structure, concept and scientific mindset of MI/SD Class Teachers (fields of study in Civics, Indonesian Language, Mathematics, Science, and Social Sciences).

Assessment of general skills includes: 1) compiling a scientific description, the results of the study in the form of a thesis or final project report, and uploading it on the university's website; 2) able to make the right decisions, in the context of solving problems in their area of expertise based on the results of information and data analysis; 3 ) able to carry out the process of selfevaluation of the work group under their responsibility and able to manage learning independently; and 4) able to document, store, secure, and retrieve data to ensure the validity of preventing plagiarism.

Assessment of specific skills, including: 1) being able to carry out assessments and evaluations of learning processes and outcomes in the field of MI/SD Class Teachers (field of study PKn MI/SD, Indonesian MI/SD, Mathematics MI/SD, IPA MI/SD, IPS MI/ SD) appropriately, and 
Volume 2 (3) 2021

E-ISSN: 2723-6919 P-ISSN: 2746-0827

able to use it for learning purposes; and 2) able to take reflective actions and use information and communication technology to improve the quality of learning in the field of MI/SD Class Teachers (fields of study in Civics MI/SD, Indonesian MI/SD, Mathematics MI/SD, IPA $\mathrm{MI} / \mathrm{SD}$, IPS MI/ SD).

A teacher doing CAR will have a positive impact on: a) increasing the ability to solve educational problems and learning problems that are actually faced, b) improving the quality of input, processes, and learning outcomes, c) increasing the professionalism of educators, and d) applying the principles of research-based learning. The findings obtained based on research can be used to overcome problems in the subsequent learning process so that there is an increase in the quality of learning (Wening, 2012).

CAR can be used to improve educator competence because: 1) it is carried out collaboratively between teachers and resource persons, 2) education and learning problems can be studied, improved, and resolved, 3) it fosters a learning culture among teachers and students in schools, 4) it provides opportunities as a performance development strategy by solving learning problems, and 5) this research approach positions educators as researchers as well as agents. As a result, a professional educator is essential to conduct CAR in each lesson because the purpose of CAR is to increase learning quality. Implementing CAR can assist teachers in resolving learning challenges in their classes, as well as enhance the number of Scientific Writing (KTI) reports that meet promotion/rank requirements (Novita, 2018; Wening, 2012).

CAR is one of the techniques so that learning managed by teachers/lecturers increases through continuous improvement (Sanjaya, 2013). This means that learning quality must be evaluated from two perspectives: the learning process and the evaluation of learning outcomes/assessments. As a result, every lecturer is obligated to take action in the classroom at all times in order to improve the quality of learning. CAR is intimately linked to a lecturer's professional responsibilities, which comprise the core dharma of higher education, namely education and teaching (Hayati et al., 2018).

Based on the theory and the researcher's initial findings, the researcher looks at previous studies that support the importance of this research study. First, research by Fitria et al. (2019) which revealed that the benefits of CAR include helping teachers improve the quality of learning, increasing teacher professionalism and increasing teacher competence. Second, research by Arsanti (2018) suggests that from the results of the needs analysis it is known that students need teaching materials in the form of textbooks that are in accordance with textbook eligibility standards which include (1) the feasibility of the content of the material, (2) the feasibility of presentation, (3) the appropriateness of language, and (4) the feasibility of graphics. The characteristics of the teaching materials are (1) self-instructional, (2) selfcontained, (3) stand alone, (4) adaptive, and (5) user friendly. The three studies by Kasina \& Lestari (2010) found the level of readability of teaching materials for the Elementary School Child Development course was quite high, which means that the teaching materials were easy for students to understand. In addition, the mastery of the content of teaching materials by students is good. From some of the reasons that the researcher has stated above, the researcher sees that the study in this research is important to research so that the product of this research is able to answer the needs of students for textbooks for CAR methodology courses. 


\section{B. Methods}

The design model of this development research is Recursive Reflective Design and Development (R2D2) which was developed by Willis (1995) based on constructivism view. This design was chosen because it is reflective, recursive, collaborative, and dynamic, allowing researchers and other interested parties to build learning goods, such as textbooks, that are in line with the demands on an ongoing basis until the very appropriate product, accurate, efficient, and effective is determined.

The research and development procedure consists of three stages, namely (1) definition, (2) planning and development, and (3) dissemination. The defining activity is focused on (1) creating teamwork (2) progressive problem solutions, and (3) understanding the problem contextually. Planning and development activities are focused on (1) studying the learning context, (2) selecting formats and media, (3) determining evaluation strategies, and (4) designing products and their development. Dissemination activities are focused on (1) authentic evaluation, and (2) preparation of the final product package according to the context.

The feasibility of the developed product can be seen after the product test is carried out. The product test consists of expert test, practitioner test (lecturer), and user test (student). Based on the results of the product test, a revision was made to the developed textbook model.

The test subjects of this research product include three groups. First, an expert group consisting of three CAR methodology experts. Second, the group of lecturers consisting of three lecturers of the CAR methodology course. Third, the student group consisting of ten students from the FTK UIN Sulthan Thaha Saifuddin Jambi.

Data was collected by giving questionnaires and suggestion sheets to product test subjects. Questionnaire for CAR methodology subject experts and lecturers related to the accuracy of the concept of lecture material, presentation of material, language, and graphics consisting of 28 statements. Questionnaire for students related to the practicality of using textbooks consisting of 12 questions. The answer choices for the questionnaire are in the form of a scale of 1-5 with a gradation nature (score $1=$ very inappropriate, $2=$ not feasible, $3=$ less feasible; $4=$ appropriate; and $5=$ very feasible $)$.

The data of this research is validation data from the development of textbooks obtained when testing the product. The numerical data from the questionnaire was analyzed using the percentage technique, while the verbal data in the form of criticism, suggestions, and comments written on the textbook model file or the assessment instrument sheet were analyzed using domain analysis techniques with critical and reflective principles. The results of the assessment in the product test through an assessment questionnaire show the quality of the developed textbook model draft. Input in the form of criticism, suggestions, and comments shows the expectations of the product test subjects so that the textbooks are arranged better. The data is used to revise and improve the textbook model.

\section{Results and Discussion}

This development product is in the form of a CAR methodology textbook model based on a process approach for students of the FTK UIN Sulthan Thaha Saifuddin Jambi. The textbook for this CAR methodology course is entitled "Classroom Action Research: Principles and 
Practices of Data Collection Instruments". This textbook model consists of three parts, namely: 1) an introduction, 2) a content section, and 3) an additional section. The introductory section consists of a cover, a preface and a table of contents. The content section consists of eleven chapters, which include: 1) recall of CAR concepts; 2) research techniques and CAR data collection instruments; 3) observation sheet; 4) interview sheet; 5) test sheet; 6) questionnaire sheet; 7) documentation in CAR; 8) analysis techniques in CAR; 9) dissemination of CAR reports; 10) write articles from the results of the CAR; and 11) writing a book based on the results of the CAR. The additional part is a bibliography and bonus powerpoint teaching materials.

The data from the expert test shows that the textbook model developed is in the appropriate category (mean score 3.59). Suggestions or expert comments on the textbook model are: (1) improving the accuracy of the use of spelling, (2) improving the use of terms and vocabulary; and (3) it is necessary to add a chapter on writing articles from the results of the CAR and a chapter on writing books from the results of the CAR. Based on these suggestions, a revision of the textbook model has been made. The improvements include: (1) improvements to the use of spelling; (2) improvement in the use of more precise terms or vocabulary; and (3) the addition of two chapters: one on writing articles, and another on writing books based on the CAR's findings.

The data from the practitioner (lecturer) test results show that the textbook model developed is in the very feasible category (mean score 4.32). Suggestions or comments from practitioners (lecturers) are (1) improving the accuracy of the use of spelling; (2) improving the use of terms and vocabulary; and (3) improvement of writing the title of the text in accordance with the referenced text. A revision of the textbook model has been done based on these ideas or criticisms. The following modifications were made: (1) enhancing spelling accuracy; (2) improving the usage of terms and vocabulary; and (3) improving the wording of the text title in accordance with the referenced text.

The data from the user (student) test results show that the textbook model developed is in the very feasible category. Suggestions or comments from users (students) are (1) replacement of words that contain difficult meanings; (2) improvements to the layout and images to make them more attractive; and (3) clarity of assignment, whether done individually or in groups. Based on these suggestions or comments, a revision of the textbook model has been made. The improvements made include (1) the accuracy of the use of words; (2) layout and drawings; and (3) firmness in giving assignments individually or in groups.

In a university, CAR methodology courses are significant as a means for aspiring pre-service teacher to improve their effectiveness and get the functional roles they desire (Miaz, 2015). Thus, in order to improve learning outcomes and the quantity of publication of student articles from the results of the CAR in the CAR methodology course, a printed media of textbooks for the subject was developed. The development carried out through this research is carried out by creating the novelty value/excellence of this book in several ways, as described below.

The method of teaching the content begins with the presentation of the fundamental ideas of CAR. This proved to be quite beneficial to readers and researchers, particularly in terms of comprehending CAR. Figure 1 shows how the basic concepts of CAR were introduced during the production of this book. 


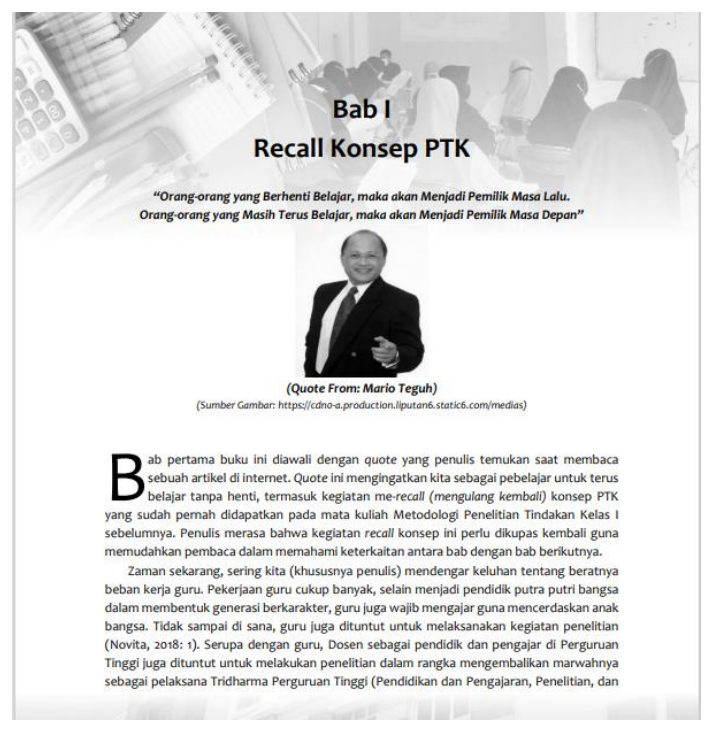

The provision of an example of a CAR proposal that has complied with the writing rules and concepts of CAR as a student guide in writing a CAR proposal. The results showed that during the Classroom Action Research Methodology lecture at FTK UIN Sulthan Thaha Saifuddin Jambi, students found it easy to prepare CAR proposals because of the CAR examples included in this book. The form of presentation of examples of CAR proposals in the development of this book, can be seen in Figure 2 below.

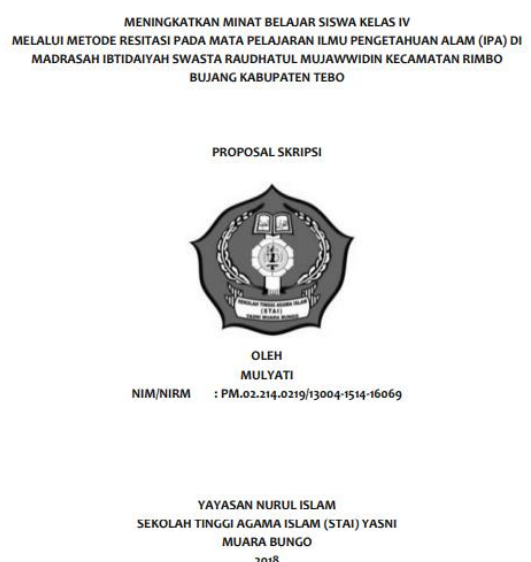

This book presents the sub-concepts of each Data Collection Instrument in a complete and systematic CAR. The presentation and development in this book, which is related to the systematic way of presentation for each IPD, starts from: definition, the importance of the IPD in CAR, Requirements for a good IPD in CAR, Examples of IPD during grandtours and cycles, advantages and disadvantages of the IPD, validity and the reliability of the IPD. The form of presentation related to systematization in the explanation of each IPD in the development of this book can be seen in Figure 3 below. 


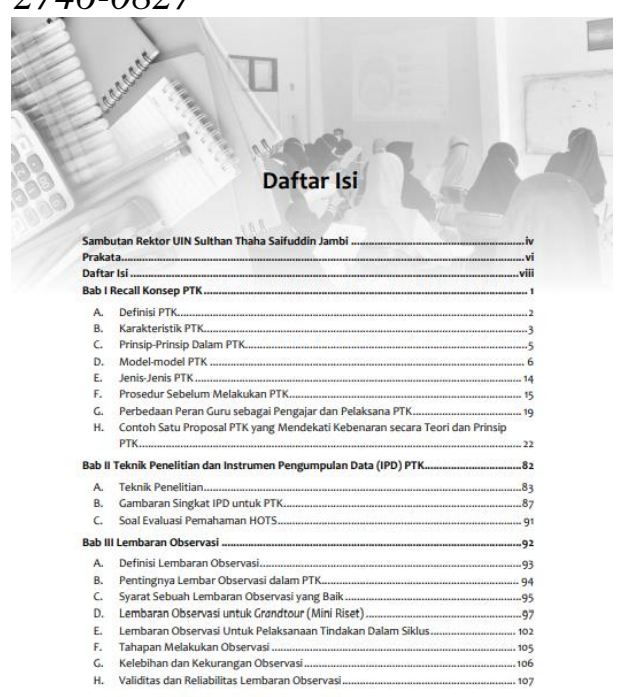

This book also presents material on how to convert CAR reports into national scientific articles and books. This is the main point of this book. The results showed that students better understand how to convert or transform CAR reports into scientific articles by presenting the material in this book. This is evidenced by the publication of three student scientific articles from the CAR reports he did in accredited national journals. The form of exposure related to how to convert CAR reports into national scientific articles and books on the development of this book, can be seen in Figure 4 below.

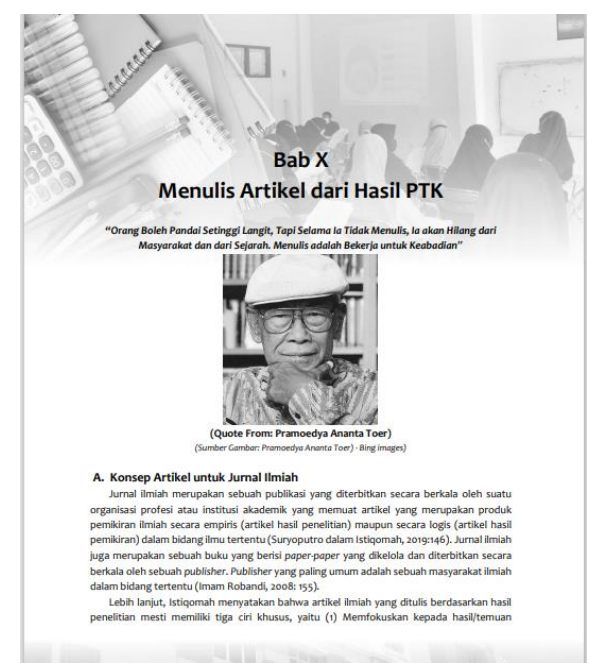

Teaching materials are a collection of written and unwritten resources that are presented in a systematic manner to create an environment/atmosphere in which students can learn (Sudrajat, 2008). Because it will be utilized by educators to assist and support the learning process, teaching materials should be planned and prepared with instructional rules. Teaching materials are also a collection of learning materials (teaching-materials) that are organized in a systematic manner to display a complete figure of competencies that students will master during learning activities. Students can study a competency or a basic competency in a cohesive and methodical manner using instructional materials, allowing them to master all competencies in a cumulative and integrated manner. Teaching materials relate to the curriculum (in this example, the lecture 
syllabus) that is utilized to accomplish predetermined competency criteria and basic competencies (Arsanti, 2018). It may be concluded that teaching materials must be created in order for the teaching and learning process to go properly.

Several specialists organize educational resources depending on their type in a variety of ways, each with their own justifications at the time of grouping. Heinich et al. (1996) divide teaching materials into five categories based on how they work: a) non-projected teaching materials, such as photos, diagrams, displays, and models; b) projected teaching materials, such as slides, film strips, overheads, transferences, and computer projections; c) audio teaching materials, such as cassettes and compact discs; d) video and film teaching materials; and e) computer teaching materials (media), such as copier and printer.

Ellington \& Race (1993) classified educational resources into seven categories based on their form, including: a) printed teaching materials and their duplicates, for example handouts, worksheets, self-study materials, group study materials; b) display teaching materials that are not projected, such as flipcharts, posters, models and photos; c) audio teaching materials, for example audio discs, audio tapes and radio broadcasts; d) projected still display teaching materials, for example slides, film strips, etc.; e) audio teaching materials that are linked to silent visual materials, for example sound slide programs, sound flimstrip programs, model tapes, and reali tapes; f) video teaching materials, for example television broadcasts and video tape recordings; and g) computer teaching materials, such as Computer Assisted Instruction (CAI) and Computer Based Tutorial (CBT).

Teaching materials are divided into two categories by Sitohang (2014): printed teaching materials and non-printed teaching materials. The types of printed teaching materials referred to in this basic material book are modules, handouts, and worksheets. Meanwhile, what is included in the category of non-printed teaching materials is reality, teaching materials developed from simple items, silent display teaching materials, video, audio, and Overhead Transparency (OHP).

When a group of individuals (students) identify an issue, the researcher (teacher/lecturer) decides on a course of action to fix the problem. The researcher observes the success or failure of the action as it is taking place. Classroom action research blends meaningful activity with research processes in an attempt to solve problems while seeking scientific support (O'Brien, 2001). CAR is a study undertaken in the classroom by teachers, lecturers, students, and researchers based on the outcomes of self-reflection with the goal of increasing the quality of learning through cycles.

The principles that need to be applied in conducting CAR include: 1) actions and observations in the research process that are carried out do not interfere or hinder the main learning activities being carried out by the teacher, for example, the teacher must not sacrifice activities or the teaching and learning process; 2) the problem or topic to be researched must be really interesting, real, not difficult, solvable, and within the reach of the researcher to make changes. Researchers should feel called to improve themselves; 3 ) the methodology used is carefully planned so that actions can be formulated in an action hypothesis that can be tested in the field; 4) the methods and techniques used are not too demanding on the teacher's ability and implementation time; 5) data collection is unobtrusive and time-consuming; 6) pay attention to research ethics, confidentiality and applicable implementation guidelines; and 7) research 
activities must be sustainable for the improvement and development of learning (Wening, 2012).

This study is in line with the findings of a study by Fitria et al. (2019) which revealed that the preparation of CAR in the form of a journal would be beneficial for increasing the rank or functional position of teachers. This research is also supported by Yunita et al. (2020) which revealed that the function of classroom teacher education management can improve student learning outcomes. Furthermore, research by Syamsi et al. (2013) is in line with this study which revealed that the reading textbook model had been developed based on the process approach and the text book consisted of three parts, i.e. (1) introduction, (2) core materials, and (3) additional parts. Each unit consists of the title, competence, pre-reading, whilst-reading, responding, exploring the text, and extending comprehension.

\section{Conclusion}

The printed media for teaching textbooks of the CAR Methodology course has been developed based on a process approach. The book consists of eleven chapters, covering: 1) recall of CAR concepts; 2) research techniques and CAR data collection instruments; 3) observation sheet; 4) interview sheet; 5) test sheet; 6) questionnaire sheet; 7) documentation in CAR; 8) analysis techniques in CAR; 9) dissemination of CAR reports; 10) write articles from the results of the CAR; and 11) writing a book based on the results of the CAR. The purpose of learning with print media is to help students learn the CAR methodology easily and make learning interesting and fun and enable them to study independently. The developed learning print media is claimed to be suitable for use through a feasibility test carried out by material and media experts to practice making CAR proposals or reports to publishing ISBN articles and books from the CAR results.

\section{E. Acknowledgement}

We would like to express our special thanks and gratitude to our Rector of Universitas Islam Negeri Sulthan Thaha Saifuddin Jambi, Institut Agama Islam Yasni Bungo, Universitas Islam Negeri Fatmawati Sukarno Bengkulu and friends who gave us support to carry out this extraordinary project.

\section{References}

Arsanti, M. (2018). Pengembangan Bahan Ajar Mata Kuliah Penulisan Kreatif Bermuatan Nilai-Nilai Pendidikan Karakter Religius Bagi Mahasiswa Prodi PBSI, FKIP, UNISSULA [Development of Teaching Materials for Creative Writing Courses Containing Religious Character Education Values for Students of PBSI Study Program, FKIP, UNISSULA]. Jurnal Kredo, 1(2).

Astuti, J., Novita, M., \& Ismail, M. S. (2020). Peningkatan Motivasi Belajar Menggunakan Contextual Teaching and Learning di Madrasah Ibtidaiyah Swasta Raudhatul Mujawwidin Tebo [Increasing Learning Motivation Using Contextual Teaching and Learning at Raudhatul Mujawwidin Private Madrasah Tebo]. Jurnal Educative: Journal of Educational Studies, 5(1), 16-28.

Depdiknas. (2006). Pedoman Penulisan Buku Pelajaran, Penjelasan Standar Mutu Buku 
Pelajaran Bahasa Indonesia [Guidelines for Writing Textbooks, Explanation of Quality Standards for Indonesian Language Textbooks]. Pusat Perbukuan, Departemen Pendidikan Nasional.

Ellington, H., \& Race, P. (1993). Producing Teaching Materials: a Handbook for Teachers and Trainers [Producing Teaching Materials: a Handbook for Teachers and Trainers]. Kogan Page.

Eriyadi, S. (2008). Community: Surat Pembaca: Merangsang Kreativitas Guru Menyusun Bahan Ajar [Community: Reader's Letter: Stimulating Teacher Creativity in Developing Teaching Materials]. Retrieved 03 May 2010. http://www.radarsemarang.com/community/artikeluntukmu-guru-ku/2259-merangsang-kreativitas-gurumenyusun-bahan-ajar.html

Fitria, H., Kristiawan, M., \& Rahmat, N. (2019). Upaya Meningkatkan Kompetensi Guru melalui Pelatihan Penelitian Tindakan Kelas [Efforts to Improve Teacher Competence through Classroom Action Research Training]. Abdimas Unwahas, 4(1), 14-25.

Hayati, D., Hamid, H., \& Syahni, R. (2018). Pengembangan Metode Cooperative dan Collaborative Learning dalam Pembelajaran Mata Kuliah Rancangan Percobaan (Proposal Hibah Topik Pengembangan Metode Pembelajaran Dan Penilaian Mahasiswa) [Development of Cooperative and Collaborative Learning Methods in Learning Experimental Design Courses (Grant Proposal Topics Development of Learning Methods and Student Assessment)]. http://repo.unand.ac.id/13070/1/PTK Proposal\%2C Nilai.pdf

Heinich, R., Molenda, M., Russel, J., \& Smaldino, S. (1996). Instructional Media and Technologies for Learning (Fifth Edition) [Instructional Media and Technologies for Learning (Fifth Edition)]. Prentice-Hall Inc.

Kasina, A., \& Lestari, E. (2010). Pengembangan Bahan Ajar Perkembangan Anak Usia SD Sebagai Sarana Belajar Mandiri Mahasiswa [Development of Teaching Materials for Elementary Age Child Development as a Means of Independent Learning for Students]. Perspektif Ilmu Pendidikan, 22(XIII), 183-193. https://media.neliti.com/media/publications/259567-pengembangan-bahan-ajarperkembangan-ana-469508a8.pdf

Miaz, Y. (2015). Penelitian Tindakan Kelas bagi Guru dan Dosen [Classroom Action Research for Teachers and Lecturers]. UNP Press Padang. http://repository.unp.ac.id/71/1/BUKU 1.pdf

Muslich, M. (2010). Text Book Writing, Dasar-dasar Pemahaman, Penulisan, dan Pemakaian Buku Teks [Basics of Understanding, Writing, and Using Textbooks]. Ar-Ruzz Media.

Novita, M. (2018). PTK tidak Horor [PTK is not Horror]. Surabaya: Pustaka Media Guru.

O'Brien, R. (2001). an Overview of the Methodological Approach of Action Research. Faculty of Information Studies. http://www.web.ca/robrien.html

Sanjaya. (2013). Strategi Pembelajaran Berorientasi Standar Proses [Process Standard 
Sitohang, R. (2014). Mengembangkan Bahan Ajar dalam Pembelajaran Ilmu Pengetahuan Sosial (IPS) di SD [Developing Teaching Materials in Social Science Learning (IPS) in SD]. Jurnal Kewarganegaraan, 23(02), 13-24. http://digilib.unimed.ac.id/1457/1/Fulltext.pdf

Sudrajat, A. (2008). Pengembangan Bahan Ajar [Development of Teaching Materials]. Retrieved 03 May 2010. http://akhmadsudrajat.word-press.com/2008/01/24/downloadpengembangan-bahan-ajar/

Syamsi, K., Sari, E. S., \& Pujiono, S. (2013). Pengembangan Model Buku Ajar Membaca Berdasarkan Pendekatan Proses bagi Siswa SMP [Development of a Reading Textbook Model Based on a Process Approach for Middle School Students]. Cakrawala Pendidikan, XXXII(1), 82-90.

Wening, S. (2012). Penelitian Tindakan Kelas [Classroom Action Research]. Modul Pendidikan Teknik Boga Dan Busana.

Widodo, C. S., \& Jasmadi. (2008). Panduan Menyusun Bahan Ajar Berbasis Kompetensi [Guide to Developing Competency-Based Teaching Materials]. PT Elex Media Komputindo.

Willis, J. (1995). a Recursive, Reflective Instructional Design Model Based on ConstructivistInterpretative Theory. Educational Technology, 35(6), 5-23.

Yunita, E., Arafat, Y., \& Mulyadi, M. (2020). The Function of Class Teacher Educational Management in Improving Student's Learning Outcomes. Journal of Social Work and Science Education, 1(2), 168-180. https://doi.org/https://doi.org/10.52690/jswse.v1i2.46 